\title{
The Potential of Biofuels in Brazil and Argentina for the Biobased Economy
}

Paulo Cesar Manduca* and Mauro Berni

University of Campinas, Campinas - SP, 13083-970, Brazil

\begin{abstract}
Argentina and Brazil occupy a prominent position among the largest exporters of biomass, biofuels inclusive. They have potential to overcome traditional role as exporter of row material and assume the vanguard of a future biobased economy. In the for now incipient frame of the biobased economy, biofuels are the most promising element since most developed countries have already established some goal of change oil to biofuel. What create a global market for ethanol and biodiesel and consequently a capital flow into the productive chain so making the productive factors - demand, competition, innovation, improvement of economic agents and market expansion - go ahead in order to develop more and more.

Despite great development on biofuel field biobased economy faces huge battle to overcome oil economy that dominates all economy fields for more than one century. Even in Brazil and Argentina the future of the biofuel is unclear the analysis highlights that both countries have recently become great producers of fossil energy. So the irresistible of fossil's force attracting and the emergence of oil populism have pushed these countries into two ways: to invest in innovation in bioefuels and other field of biobased economy or develop traditional industries linked to fossil fuels.
\end{abstract}

\section{Introduction}

Just as the emergence of oil in the 19th century has led to new economic dynamics, with new products and processes, new energies have the potential to bring another revolution on productive activities through new technologies, processes, and products by changing relationship of societies toward nature and toward other societies.

Oil reached this status by the spectacular dynamics of the American automotive industry at the beginning of the 20th century in its internationalization process when its by-products (gasoline, diesel) became the fuels for motor vehicles following the standardization of engines. The World War I gave a boost in this process since in the WWI the cavalry was replaced by the motorized infantry what turned the oil a huge strategic good.

As free-market economy spread out, oil reached the top position as feedstock. Its countless by-products fuel the petrochemical, which gives rise to a huge range of raw material for the general industry such as plastics, fibers, solvents, detergents, medicines, fertilizers etc. Consequently the oil industry has become the most powerful and branched field of the world economy, with direct or indirect participation in all productive sectors and strong political connections [1].

After more than a century of oil dominance, today's societies have to deal with its negative consequences. One of them is related to access to the benefits of modern economy since about $13 \%$ of the world's population (in 2014) still living in the curse of poverty and about 1.06 billion people still living out of electricity at home. Promoting the integration of this large part of the population with the benefits of the developed world is the UN [2] goal expressed in "The Road to Dignity by 2030: Ending Poverty, Transforming All Lives and Protecting the Planet (Synthesis Report of the Secretary- 2015 Agenda).

The overcoming of poverty with current paradigm depends on growth of economy, with the consequent increase of employment and income. But growing up in the fossil economy means to explore more, to burn more, and to generate more GHG emissions, and this comes up against another issue related the environmental consequences of current production and consumption patterns. So, as scientists point out that climate catastrophes tend to hit more severely the planet's poorest areas, it would a contradiction if they fight poverty by increasing exposure of communities to negative climatic events.

In "The Road to Dignity by 2030", world community proposes to provide universal access to electricity and development in a sustainable way, which mean to use less fossil sources. The shift from the current paradigm of economy and energy to the self-sustaining mode of production and adoption of alternative energy sources will inevitably lead to significant changes in the production processes giving rise to new production chains - products, processes and energy. In this context, biomass tends to occupy a central role once its productive chain links agriculture and industry with high potential for employment and income generation as well as potential new materials and raw materials that can replace those from fossil.

This work focuses on the Brazil and Argentina's potential role in this new economic paradigm - biobased economy. Since both are large biomass-producing countries - among the largest food exporters - and huge developers of biomass energy (biofuels). The question is whether such countries can translate their importance into the biomass production (and biofuels) in a leading position in the biobased economy as a whole. In this way, overcoming the traditional role as suppliers of raw materials to the central economies and becoming themselves players at the forefront of the new cycle of the world economy.

In the for now incipient frame of the biobased economy, biofuels are the most promising element since most developed countries have already established some goal of change oil to biofuel. What create a global market for ethanol and biodiesel and consequently a capital "Corresponding Author: Dr. Paulo Cesar Manduca, University of Campinas, Campinas - SP, 13083-970, Brazil; E-mail: manduca@unicamp.br

Citation: Manduca PC, Berni M (2018) The Potential of Biofuels in Brazil and Argentina for the Biobased Economy. Int J Earth Environ Sci 3: 151. doi: https:// doi.org/10.15344/2456-351X/2018/151

Copyright: (c) 2018 Manduca et al. This is an open-access article distributed under the terms of the Creative Commons Attribution License, which permits unrestricted use, distribution, and reproduction in any medium, provided the original author and source are credited. 
flow into the productive chain so making the productive factors demand, competition, innovation, improvement of economic agents and market expansion - go ahead in order to develop more and more.

Another vital issue to the evolution of the biofuel production chain in many countries is that biofuels has led to the emergence of a social base linked to the each stage of production. They are farmers, workers, entrepreneurs, investors, researchers, etc. who have organized themselves into associations in order to push pressure on the decision makers in order to create the good conditions for the development of the market. This social base of biofuels faces the social base linked to the status quo (in this case the oil's social base) in a dispute over influence on political system and survival. This is a essential dynamics in democracies since no one wants to disappear from the market and surviving sometimes depends on avoid the raising of a new players.

Brazil and Argentina have their own experiences in the field of biofuels. They have managed to translate their role as major producers of biomass into the major producers of biofuels. The organization of the sector and the maturity of the production chain give them the conditions to take the next step and convert the initial force into new processes and products in the biobased economy.

\section{Economics Cycles and Biobased Economy}

Biobased economy can be understood as an economic cycle whose dynamics comes from biobased row processed by reduced environmental impact method. It necessarily implies replacing fossil as fuel and as feedstock.

The expectation of the emergence of a new phase of the economy allude the theses on cycles of world economic development. The first author to defend this idea is Kondratieff, a soviet economist from the Leninist era who defended the idea that capitalist economies advances through long cycles of about 50 years of growth interspersed of a time of crisis.

In 1939 and 1942 Joseph Schumpeter [3] developed a version of Kondratieff theory focusing on innovation as main element of the cycles of prosperity in capitalist economies. It means, in free-market economies a cycle is exhausted when goods and processes have already reached their maximum capacity to induce consumption (it means economic crisis). A new cycle of economic growth starts when a set of innovations allows the emergence of new goods and processes to replace those outdated ones, offering a superior degree of quality, efficiency and adequacy in compared with old ones. An illustrative example comes from distribution of audiovisual content that, about 30 years ago were distributed as vinyl records and celluloid and $\mathrm{k} 7$ tapes. Those were first replaced by CDs/DVDs and are now being distributed by streaming. In each stage, new goods offer many gains on quality and adequacy compared to the previous one and the expectation of enjoying these gains lead the consumer to exchange old goods by news one. But that has two sides. Adhering to the new standards creates a dynamic of growth in the sectors linked to new goods. But on the other hand there is a complete abandonment of the sectors related to the old products.

Schumpeter referred to this process as "creative destruction." The term "creative destruction" comes from the perception that in this process of replacing goods and processes, everything that is linked to technologically lagged processes and goods is gradually extinct. It means: jobs, companies and the social dynamics surrounding them, such as unions, associations, traditions, lobbies and lobby groups and companies operating in the CD/DVD market dealt with factors - preferences, market constraints, regulations, rules, taxes, profit expectations etc. - which will be extinguished as consumer habits turn to streaming. In short, the construction of the new cycle of expansion of the economy implies the destruction of what characterizes the decadent cycle wile it rebuilds all new.

The cycles of the world economy are also structurally linked to energy sources - abundance or restriction of energy. Recalling that the easy availability of oil that happened since 1870 - when Standard Oil Company was created - coincided with huge world economic expansion two world wars and the NY stock market crash in 1929. Impossible to understand the expansion of world trade without the revolution in transport based on fossil fuel.

This cycle lasted for 100 years until crises in Middle East in 1973 and 1979 hit the world oil market with systemic consequences on world economy. Following the oil crises came a long period of stagnation in developed economies and especially in the under developing economies so severe that 1980 's is called "the lost decade" by authors.

The cycles of expansion of the capitalist economy have been surely strongly linked to huge innovation waves. The linking between the all elements mentioned is surely complex, but it is evident that innovations are at the root of any cycle of economic expansion. Innovation is not only in the basis of productions of goods but also in the way of obtaining energy. The emergence of the biobased economy - if it is not just projections of intellectuals within its offices - depends on this complex network of elements but it has some specificities.

1. There is no crisis in the oil's economy if only endogenous factors are taken into account: innovation, investment, stability, profit expectation, etc. It is all working well.

It means that forecasts like Hubbert Peak, instabilities due to strategic issues (Middle East war, Russian blackmail) and other predictions related to the collapse of the oil market got out of date. In fact, the technologies for exploration of super-deep waters reserves and the flux of tight oil (from shale drilling) have put out all prediction over crash of oil supply. In the other hand, strategic tensions in the Middle East dropped after the end of US war in Iraq and nuclear agreement with Iran. Both cases lead the reintegration of those two great producers into the international market. The abundance of oil in recent years has caused an OPEC internal crisis and a price war between producers what has keeping prices low around $\$ 50$ per barrel.

2. Innovations in the field of biobased economy are still in the initial phase demanding huge investment of human and financial resources and with a high degree of uncertainty regarding the risks of investments. It also comes up against cultural issues regarding the need to change consumption habits. Nothing guarantees that innovations will occur beyond what has been achieved so far. At this moment the predominant factor related to the biobased economy lies in the social dynamics related to the pressures to revert the environmental degradation resulting from the current productive models. From this arise flows of investment in innovation as well as policies to encourage the production and consumption of biomass-based products. The public policies of introducing biofuels into the energy matrixes of many countries are the prime example of this social pressure. 
There are not crisis in oil economy. But the oil industry has charged a very high price in environmental terms, so in many societies the pressure for alternatives has growing. These pressures get more serious when the scientific community presents projections on global environmental collapse caused by GHG emissions. The chances of the emergence of new, non-fossil-dependent production patterns lies in the cultural war currently waged among the status quo - a giant, billion-dollar oil's lobby - and those proponents of new production patterns.

Assuming that high prices and expectation over oil shortages have being allied to alternative energy, nowadays low prices of oil makes the biobased even less competitive than oil's by-products. What possibilities open up in this new context? The International Energy Agency (2016) points out the exit is in politics and not in economy: The energy transition is underway, but needs a strong signal from the COP21-Paris/2015: governments must establish policies against market swings (World Energy Outlook 2015 - presentation). In other word, the transition depends on the adoption by countries - jointly and in particular - of goals to replace fossil sources despite the oscillations in oil prices. In this way, the cultural war gets harder since it puts governments between liberal rationality (no intervention in the economy) and adherence to environmental regimes that imply a high degree of state intervention in the economy.

There are two lines on the edge of innovation from Silicon Valley running at the same time related to energy and transportation which can revolutionize the economy and contribute greatly to reducing the dependence on oil and its by-products. According to Tony Seba (from Stanford University) in his recent book ("Clean Disruption of Energy and Transportation: How to Make Oil, Nuclear, Natural Gas, Coal, Electric Utilities and Conventional Cars Obsolete by 2030") alternative models of business and dramatic drop in Wind and Solar costs will render most of the electricity infrastructure obsolete, while evolution of Electric Vehicle will make obsolete the oil industry (actually liquid fuels for land transport) and huge part of the carmakers.

In fact, even if Seba's ideas can be on the way, at least at the California super advanced bubble, the rest of the world should not underestimate the power of the oil's world - the quo - in the cultural ware specially in the United States of Trump.

\section{Biofuel in Brazil and Argentina}

Argentina and Brazil have become global references for biofuels production. International prices of petroleum in the second half of the 2000s provided a great incentive for the two agricultural powers whose biodiversity properties, lands, and hydric resources made them strong prospective players in the renewable energy market.

A far more successful biofuel market experience was the ethanol program, in which Brazil has 40 years of experience in the complete cycle: from feedstock production, mills, logistics and flex fuel engines. The ethanol program started under the name of Proalcool in 1975, as a Brazilian response to the petroleum crisis. The project started in the universities, and when it was taken over by the government it became a substantial national effort, including the development of engines, technology, processes, and logistics. It was a program of massive substitution of petroleum by-products for sugar cane ethanol, which has been produced in Brazil since the colonial period. The sugar industry, therefore, offered initial support for the introduction of ethanol, and the flexibility to produce both products at a scale that is convenient for the market, which is a peculiarity of the Brazilian production model: an attribute that has guaranteed the survival of the industry in times of crisis. With Proalcool, sugarcane began to be planted on a massive scale in the southwest of the country, where productivity was better, with a huge impact on the traditional mixed-crop landscape in the state of São Paulo.

The government promoted new fuel as it gave incentives to hydrated alcohol-powered vehicles as it changed all government's fleet by new cars alcohol only fueled and blended gasoline with $25 \%$ of anhydrous ethanol. In this way, barely after the second oil crisis, $60 \%$ of all cars in Brazil were ethanol fueled only.

In the second half of the decade, however, the ethanol initiative met two major crises: a substantial decline in incentives due to high government debt levels, followed by the fall of oil prices. During ten years of stagnation farmers and mils survived thanks sugar market.

After 1997, stakeholders created the Sugarcane Industry Union UNICA, which gave the sector a professional lobby. The producers, researchers, and supporters of clean energy saw in ethanol a potential substitute for petroleum derivatives. But the deficit of the industry was huge and included cases of slave-like labor, environmental damages, and subsidy dependence, and the risk that the expansion of the sugarenergy sector would threaten Pantanal and Amazon ecosystems.

The stakeholders established agreements as way treat those issues and to promote Brazilian ethanol abroad while Brazil became more constructive toward to international goals of reduction of GHGs emissions. The government then promoted a coordinated action for the international promotion of Brazilian ethanol, called "Ethanol Diplomacy" [4], with the aim to attract investments, increase foreign production and open new consuming markets.

The first decade of 2000's was being profitable for Brazil's ethanol internationally as well. EU's initiatives to enroll biofuels in the energetic matrix ${ }^{1}$ placed Brazil in a highlighted position due to 40 years of accumulated experience in the ethanol program. With EU's initiative, bases for ethanol's international market were launched. In 2010 American Environment Protection Agency - EPA - certified Brazilian ethanol as an advanced biofuel and it opened good expectation for exporters.

Argentina stated it huge production of biofuel producers in 2009 sustained by technology-intensive and competitive agriculture and robust vegetable oils industries. At that time the Argentinian Government established new standard of blended fuels as made the use of biodiesel and ethanol compulsory.

Biodiesel is the most important biofuel in Argentina. It is produced mainly from soybean, a cultivar that expanded in the country in the 1980s. Its production was initially increased in response to international demand and later by its addition to fossil fuels in the domestic market. Its competitiveness in this sector is a result of a group of vectors: (i) high agricultural productivity regarding soybean production; (ii) high production scale; (iii) favorable public policies; and (iv) increase in foreign demand [4]. Public funding for biodiesel contributed to boosting an economic

${ }^{1}$ Directive 2003/30/EC of the European Parliament and of the Council of 8 May 2003 on the promotion of the use of biofuels or other renewable fuels for transport (http://eurlex.europa.eu/legal-content/en/ALL/?uri=CELEX:32003L0030) 
sector already established and competitive. Argentina has one of the most modern biodiesel industries in the world [5].

In 2008 erupted hard struggle between government and farmers over export of agricultural commodities. At that time farmers wanted to take advantage of the high commodities prices while government was trying to keep food prices immune from international influences. In this way government limited the amount of grains could be exported through tax penalty. As that so-called "retenciones" (retentions) frustrated the expectation of neutralize losses in the domestic market with profit from the international market, farmers reacted with a strong strike. In this context, public policies on biofuels could bring a flash of peace since it offered an opportunity to farmers to keep exporting soybean as biodiesel - not as grain -, far from the government's control.

In 2012, 40\% of Argentina's soybean oil was processed and exported as biodiesel. So, producers expanded the industrial facilities, built biodiesel plants and increased production capacity from 0.5 million tons in 2007 to 4.1 million tons in 2012. The biodiesel developed quickly to become most dynamic field of national economy [6].

Argentina has being pressure from the main consumers because of prices whose it sells biodiesel. In this way European Union and United States want to charge Argentina's biofuel as dumping. But behind that kind of arguments and justifications lie several other issues since US's new government turn back almost all environmental regulations left by President Obamas in concert with Big Oil's interests at the same time President Trump performs its nationalist doctrine "America first" and UE - always protectionist on agricultural market issues still charging Argentina for having renationalized oil company YPF in 2011 when it was controlled by Spanish oil company Repsol.

It was then that fossil fuels crossed the path of biofuels in both countries. Firstly, because of biofuels exporters have to face with big oil's interest, secondly, by internal political issues after discovering fossil reservoirs in both countries.

The discovery of a large reservoir of deep-sea oil in the Brazilian coast (pre-salt) in 2007 and of large shale reserves in Argentina (Vaca Muerta) in 2011 brought deep repercussions over policies toward to biofuels. Those enormous reserves quickly ignited the nationalism of the leftist populist governments This nationalism clings to the idea that oil is the passport to achieve national objectives and the reserves of the pre-salt and Vaca Muerta would bring the promise of Brazil and Argentina become what they had never been: rich and powerful. The myth of the "el dorado" of petroleum that had already been in the national imaginary in the past of the two countries came to real.

This kind of petroleum populism was successful in convince societies to invest in oil industry despite that economic paradigm are running in the opposite path. In consequence, biofuel field lost it role as national priority and most of incentives given in order to develop market as well. In this way, not only farmers got losses but, all web of stakeholders did.

Nowadays, everything related to production and exportation of biofuel in Brazil and Argentina depends on the stakeholders themselves. And they are doing well in terms of international market of ethanol and biodiesel because their capability and skills. And they have initiatives in the green chemicals, what means they are exploring theirs capabilities to the edge. In Brazil, stakeholders have developed some kind of plastic based on sugarcane ethanol. Argentina kicked start to run a glycerin distillation plant, which would complement one already installed biodiesel plant capable of producing 1,600 tons of row glycerin per month. Glycerin is by-product of the biodiesel process and can be used in many ways like medicines, personal care products, etc.

\section{Conclusion}

Petroleum populism was successful in convince societies to invest in oil industry despite that economic paradigm are running in the opposite path. In consequence, biofuel field lost it role as national priority and most of incentives given in order to develop market as well. In this way, not only farmers got losses but, all web of stakeholders did.

Biofuels are still important in Argentina and Brazil, but with less attention from the State. Thus the stakeholders find many difficulties in maintaining the dynamism of the sector in order to expand the roll of products from biobased economy.

Although the future outlook for biofuels in Brazil and in Argentina appears uncertain, the historical development of biofuels represented a great leap for both economies, which had previously been largely dependent on innovation from abroad. The potential remains for expansion to bioproducts and other forms of bioenergy, should political and market conditions change. Recent data point to industry recovery but the fact that biofuels are no longer among the national priorities, indicates shows that these governments opt for traditional and outdated models of economic development in spite of the journeys traveled, the challenges achieved, and the current potential for expanding the green economy. That is to say that biofuels production is likely to proceed but neither of these governments has yet acknowledged the importance of the green economy, or the looming collapse of the petroleum economy.

\section{Competing Interests}

The authors declare that no competing interests exist.

\section{Acknowledgements}

The authors thank São Paulo Research Foundation for its support.

\section{References}

1. Lane L (2015) Oil and World Power. The New Atlantis 47: 3-17.

2. United Nations (2014) The Road to Dignity by 2030: Ending Poverty, Transforming All Lives and Protecting the Planet. Synthesis Report of the Secretary-General On the Post-2015 Agenda.

3. Schumpeter J (2003) Capitalism, Socialism and Democracy London and New York: Taylor \& Francis e-Library.

4. Dalgaard K (2012) The Energy Statecraft of Brazil: Promoting biofuels as an instrument of Brazilian foreign policy 2003-2010. PhD thesis, London School of Economics and Political Science.

5. Dolabella RHC (2011) Estudo: Biocombustíveisna Argentina: PolíticasPúblicas e EvoluçãoRecente, Área de agricultura, Pecuária, Abastecimento e Desenvolvimento Rural, ConsultoriaLegislativaBrasil.

6. Chidiak M, Rozemberg R (2016) Biofuels in Argentina Lessons Learned, Challenges Pending.

7. World Bank (2017) State of Electricity Access Report (SEAR). Washington DC. 